\title{
Direitos Humanos no Brasil: Perspectivas para um Novo Século O Tribunal Internacional de Direitos Humanos ${ }^{1}$
}

\author{
Osabela Piacentini de Atndrade
}

Acadêmica do $4^{\circ}$ ano de Direito da UFPR e membro do NUPESUL.

\section{SUMÁRIO}

Introdução;

1 Os direitos humanos na Constituição brasileira de 1988;

20 Tribunal Internacional de Direitos Humanos;

3 Possíveis obstáculos à adesão brasileira ao Tribunal Penal Internacional: aspectos constitucionais;

4 Otimização do sistema: como superar outros entraves constitucionais em relação aos tratados internacionais de direitos humanos;

5 No limiar de um novo século: o papel do Brasil perante o mundo na luta pelos direitos humanos;

Conclusão;

Referências bibliográficas.

\section{Introdução}

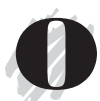

s Direitos Humanos são o grande tema do momento. Constituem matéria prioritária neste final de século. Dentro desse vastíssimo campo de trabalho, optamos por enfocar uma importantíssima previsão constitucional: a criação de um Tribunal Internacional de Direitos Humanos. $\mathrm{O}$ art. $7^{\mathrm{O}}$ do Ato das Disposições Constitucionais Transitórias preceitua que "o Brasil propugnará pela formação de um tribunal internacional de direitos humanos".

Ainda que não integre o texto permanente da nossa Constituição, esse dispositivo não pode ser posto de lado. A defesa em torno dos Direitos Humanos no Brasil não pode se restringir a simplesmente insculpir na Constituição uma gama de normas sem efetividade. E a luta por esses

1 Trabalho premiado com o $3^{\circ}$ lugar no Concurso de Monografias promovido pela OAB/PR sobre "Direitos Humanos no Brasil: Perspectivas para um novo século" em outubro de 2000. 
Direitos envolve proporções mundiais. Felizmente o Brasil, ao inserir tal dispositivo na Constituição, mostrou não estar alheio a essa batalha e, melhor ainda, revelou-se disposto a participar dela.

A criação do Tribunal Penal Internacional, esforço conjunto do Brasil ao lado de inúmeros países e organizações não-governamentais, injeta novo ânimo nessa luta e concretiza o anseio brasileiro expresso no art. $7^{\mathrm{o}}$ do ADCT.

Brasil hoje possui uma postura pacífica, é defensor dos Direitos Humanos. Mas nosso recente passado ainda está vivo na memória de muitas vítimas da repressão institucionalizada que durante 21 anos assombrou o Brasil. Se não é possível esquecer esse passado, ao menos é possível arrepender-se. Mas tão-só o arrependimento não será suficiente. É preciso comprometer-se a não errar mais e não permitir que outros errem. $\bigcirc$ Brasil, através da Constituição de 1988, assumiu esse compromisso. Avocou para si o papel de propugnar pela criação de um Tribunal Internacional de Direitos Humanos. E será realizando esse objetivo que o Brasil adentrará o novo século.

O presente trabalho tem como objetivo revelar que o art. 7ํ do ADCT está próximo de ser realizado. Com o advento do Tribunal Penal Internacional, a previsão constitucional de criação de um tribunal de Direitos Humanos será cumprida, e muito bem cumprida. Mas a importância desse acontecimento não estará restrita apenas à ordem constitucional interna. $\bigcirc$ Brasil também assumirá seu papel perante toda a humanidade. estudo divide-se em seis partes. $\mathrm{Na}$ primeira tratamos do impulso que a Constituição Federal de 1988 deu aos Direitos Humanos, ressaltando todos os dispositivos constitucionais pertinentes e, em especial, a propugnação constitucional por um Tribunal de Direitos Humanos.

A segunda dedica-se inteiramente ao Tribunal Penal Internacional como expressão da previsão constitucional contida no art. 7º do ADCT. Destaca a postura brasileira quanto ao assunto e elenca as características gerais do Tribunal.

A terceira parte visa a suprimir possíveis óbices à adesão brasileira ao Tribunal. São abordadas questões polêmicas como a prisão perpétua e a entrega de nacionais em face da Constituição brasileira.

Em seguida, tratamos da problemática constitucional em torno da incorporação de tratados à ordem interna. Procuramos suprimir entraves jurídicopolíticos para alcançar uma otimização do sistema, de modo a melhorar ainda mais a realização dos Direitos Humanos no Brasil.

Por fim, levando em consideração tudo o que foi explanado, a última parte objetiva demonstrar o papel do Brasil no limiar do novo século que se aproxima. Traça as perspectivas dos Direitos Humanos para o futuro próximo e a importância do Brasil nesse contexto.

É dessa maneira que procuramos expressar nossas aspirações referentes à temática "Direitos Humanos no Brasil: Perspectivas para o Novo Século”. 


\section{Os direitos humanos na Constituição brasileira de 1988}

\subsection{A "Constituição cidadã"}

A Constituição Federal de 1988 refletiu o contexto sociopolítico atravessado pelo Brasil e pela conjuntura mundial como um todo. A adesão maciça das Constituições deste século às movimentações em prol dos Direitos Humanos reforçou a consciência sobre a importância do tema. Após odiosos anos de ditadura militar, o problema que enfrentava o legislador constituinte originário não era a simples tarefa de elaborar novas leis. Era todo um desafio histórico de reconstruir um país arrasado nas suas instituições e restaurar no povo a confiança nas próprias forças e esperança em melhores destinos. ${ }^{2}$

O desafio de restaurar direitos fez a Constituição insculpir em seu texto amplo leque de direitos e garantias com vistas a promover os Direitos Humanos no Brasil. FLÁVIA PIOVESAN frisa que "a Constituição Brasileira de 1988 constitui o marco jurídico da transição democrática e da institucionalização dos direitos humanos no Brasil". ${ }^{3}$

\subsection{As previsões constitucionais sobre direitos humanos}

\subsubsection{A dignidade da pessoa humana: princípio fundamental}

A dignidade da pessoa humana é tida como um dos fundamentos da República

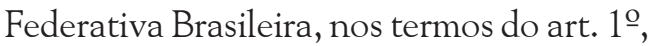
III da Constituição. $\mathrm{O}$ valor da dignidade humana foi ineditamente elevado em princípio fundamental da Carta, revelando-se núcleo básico e informador do ordenamento jurídico brasileiro. É critério e parâmetro de valoração a orientar a aplicação e compreensão do sistema constitucional, incorporando ideais de justiça e necessidade ética. ${ }^{4}$ Confere suporte axiológico a todo o sistema jurídico, sendo dotado de força imperativa no exercício da interpretação.

\subsubsection{O princípio da prevalência dos direitos humanos nas relações internacionais}

$\mathrm{O}$ art. 4을 II, preceitua que a prevalência dos Direitos Humanos é princípio norteador das relações internacionais travadas pelo país.

O dogma da soberania estatal encontra-se relativizado dentro do contexto global e de cooperação em que vivemos. Se antigamente a doutrina da soberania absoluta estipulava que os Estados deveriam apenas observar impassíveis as violações ao ser humano perpetradas por outras nações, ${ }^{5}$ hoje tem-se que os Direitos Humanos possuem relevância internacional, devendo reger as relações entre países. A problemática, portanto, atinge toda a comunidade internacional. Os princípios expressos na Declaração Universal dos Direitos Humanos de 1948 foram adotados pelas Constituições do mundo todo, de forma que

2 MARTINEZ, Paulo. Constituição: legalidade versus realidade. 4. ed., São Paulo: Moderna, 1991, p. 11.

3 "A Constituição brasileira de 1988 e os tratados internacionais de proteção dos Direitos Humanos". In Os direitos humanos e 0 direito internacional. Rio de Janeiro: Renovar, 1999.

4 PIOVESAN, Flávia. Idem, p. 128.

5 LEAL, Rogério Gesta. Direitos humanos no Brasil: desafios à democracia. Porto Alegre: Livraria do Advogado, 1997, p. 84. 
atualmente os Direitos Humanos tutelam universalmente as relações entre países.

Brasil expressa essa realidade através do art. 4ํㅡㄴ II. A prevalência dos Direitos Humanos em nível internacional é também princípio integrador e interpretativo do ordenamento jurídico brasileiro, condicionando o legislador e o aplicador da lei internos.

\subsubsection{A supremacia dos direitos humanos: cláusula pétrea}

"Art. 60. (...)

$\S$ 4ํNão será objeto de deliberação a proposta de emenda tendente a abolir: viduais."

IV - os direitos e garantias indi-

O legislador constituinte quis atribuir a certos princípios importância diferenciada em relação aos demais. São as chamadas cláusulas pétreas, disposições que não podem sofrer mudança por meio de reforma constitucional. Vedam-se emendas que alterem a forma federativa de Estado, o voto direto, secreto, universal e periódico, a separação de Poderes e os direitos e garantias individuais. Os direitos humanos integram esse último item.

Objetivo do constituinte ao prever esse dispositivo foi, mais uma vez, ressaltar a supremacia dos Direitos Humanos e sua essencialidade na manutenção do Estado de Direito. Ao lado do sistema federativo, do sistema representativo e da tripartição de poderes, os direitos e garantias individuais dão sustentabilidade e fundamento ao sistema jurídico nacional. A relevância que possuem dentro da ordem interna impede que o poder constituinte derivado, e menos ainda o legislador ordinário, disponham contrariamente aos direitos fundamentais do ser humano.

\subsubsection{Aplicabilidade imediata e rol exemplificativo do art. $5^{\circ}$}

$\mathrm{O}$ art. 5ำ da Constituição contém extenso rol (77 incisos) de direitos e garantias fundamentais (Título II). Tais normas, por força do $\S 1^{\mathrm{o}}$ desse mesmo artigo, possuem aplicabilidade imediata, ou seja, são imediatamente exigíveis e aplicáveis.

Os direitos e garantias arrolados no art. 5ํㅡㄹ entretanto, são apenas exemplificativos. $\bigcirc \S 2$ ำ preleciona que eles "não excluem outros decorrentes do regime e dos princípios por ela $(\mathrm{CF})$ adotados, ou dos tratados internacionais em que a República Federativa do Brasil seja parte". Novamente aqui o constituinte reconhece o caráter universal dos Direitos Humanos, admitindo a incorporação à ordem interna de novos Direitos que porventura não tenham constado no rol do art. 5ํ. Transparece o objetivo do legislador em evidenciar a autoridade dos Direitos Humanos dentro do ordenamento nacional e revelar sua transcendência interestatal.

\subsection{0 art. 70 do Ato das Disposições Constitucionais Transitórias: um Tribunal Internacional de Direitos Humanos}

$\bigcirc$ art. $7^{\mathrm{o}}$ do Ato das Disposições Constitucionais Transitórias expressa que "o Brasil propugnará pela formação de um tribunal internacional de direitos humanos". 
Esse dispositivo, talvez por integrar o ADCT e não o texto permanente da Constituição, é deveras esquecido, tanto pelos estudiosos como pelo legislador em geral. Entretanto, ele consubstancia a afirmação de todos os enunciados anteriores. Contém uma proposta concreta de efetivação dos Direitos Humanos. Possui conteúdo prático e não apenas principiológico como as demais previsões constitucionais. É uma norma viável e que trará enormes benefícios.

Um Tribunal Internacional de Direitos Humanos trabalhará pela dignidade humana (art. 1ํㅜ III). Expressará a prevalência dos Direitos Humanos nas relações internacionais (art. 4을 II) e a sua supremacia na ordem interna (art. 60, $\S 4$ 으. IV). Conduzirá ao reconhecimento de outros direitos e garantias de caráter humanitário (art. $5^{\mathrm{o}}, \S 2^{\mathrm{o}}$ ).

Os Direitos Humanos, já o dissemos, são princípios orientadores das nossas relações internacionais. Essa norma constitucional promoveu a adesão plena do Brasil aos tratados internacionais sobre Direitos Humanos e o reconhecimento da competência da Corte Interamericana para julgar sobre casos individuais de violações aos direitos humanos. ${ }^{6}$

A participação do Brasil na criação de um Tribunal de Direitos Humanos de abrangência internacional nos trará um enorme avanço em termos humanitários.
Os benefícios de que desfrutaremos, no entanto, não estarão restritos ao território brasileiro. $\bigcirc$ Brasil estará contribuindo, conforme suas melhores tradições, para preencher uma lacuna não apenas constitucional, mas universal. Às margens do século XXI, a humanidade não pode continuar assistindo a intermináveis e absurdas violações aos Direitos Humanos. Há urgência na criação de um organismo universal competente, efetivo e sério. $\bigcirc$ Brasil não está alheio a esse apelo.

\section{Tribunal Internacional de Direitos Humanos}

\subsection{Considerações gerais. 0 problema da impunidade}

"Muitas vezes, é inaceitável saber-se que existe o criminoso e não se ter condições para que ele seja punido. Seja o crime, de que coloração tenha sido, seja ele de colarinho branco ou não. E a verdade é que, muitas vezes, não há condições porque a Justiça não dispõe dos instrumentos para tanto, não dispõe de uma legislação adequada e muitas vezes sequer dos meios materiais para agir mais rapidamente". ${ }^{7}$ Essas foram as palavras do Presidente da República FERNANDO HENRIQUE CARDOSO ao proferir o discurso sobre os Direitos Humanos no Palácio da Alvorada, em 7 de setembro de 1995. Infelizmente revela uma realidade trágica. A impunidade dos grandes criminosos e violadores de Direitos Humanos.

6 SABOIA, Gilberto Vergne. A criação do Tribunal Penal Internacional. Conferência de abertura do Seminário Internacional sobre o Tribunal Penal Internacional e a Constituição Brasileira. Auditório do Superior Tribunal de Justiça, 29.09.1999 a 01.10.1999.

7 Direitos Humanos: o novo nome da liberdade e da democracia. Brasília: Presidência da República, Secretaria de Comunicação Social, Ministério da Justiça, Ministério das Relações Exteriores, 1995, p. 10. 
Tais criminosos muitas vezes ficam impunes porque contam com posturas tolerantes do próprio poder público. "A questão dos direitos humanos com freqüência incomoda diretamente as autoridades. Por ação ou omissão, os órgãos policiais são sempre responsabilizados por muitas das mais graves violações, como torturas e execuções extrajudiciais". ${ }^{8}$ Os casos de tortura e desaparecimentos forçados são realidades do Brasil atual, mesmo anos após o fim da ditadura. ${ }^{9}$ Às barbáries policiais somam-se massacres de índios e de trabalhadores rurais sem-terra, grupos de extermínio institucionalizados, chacinas de menores e assassinatos nas penitenciárias. A impunidade dos agentes oficiais conduz à banalização do crime e perpetuação da violência contra o ser humano.

Brasil adotou alguns mecanismos para tentar amenizar esse quadro . Criou a Lei $\mathrm{n}^{\mathrm{o}} 9.455 / 97$, sobre o crime de tortura, a Lei $\mathrm{n}^{\mathrm{o}} 7.716 / 89$, sobre preconceito racial, instalou políticas humanitárias e o Programa Nacional de Direitos Humanos. Aderiu à Convenção internacional contra a tortura e outros tratamentos ou penas cruéis, desumanos ou degradantes e à Convenção para prevenção e sanção do genocídio, para citar apenas alguns poucos exemplos. Mas todos esses esforços não lograrão resultado enquanto houver condescendência interna com as violações institucionalizadas aos Direitos Humanos. Faz-se necessária a presença de uma autoridade externa, que as- suma e execute compromissos sérios contra tais ilegalidades. A luta em favor dos Direitos Humanos não pode ser barrada por fronteiras de países, pois é universal. Precisamos de um Tribunal Internacional de Direitos Humanos.

No plano internacional, o Brasil sempre participou ativamente da luta em favor dos Direitos Humanos através de delegações conscientes e capacitadas, além da participação das organizações não-governamentais. Atendendo ao art. $7^{0}$ do ADCT, o Brasil sempre apoiou a criação de um Tribunal Internacional de Direitos Humanos.

Esse objetivo, finalmente, está próximo de tornar-se uma realidade. Em 7 de fevereiro do presente ano, o Brasil firmou o Estatuto de Roma, aderindo à criação do Tribunal Penal Internacional.

\subsection{Tribunal Penal Internacional. Posição brasileira}

O Tribunal Penal Internacional foi criado em 17 de julho de 1998 através da aprovação do Estatuto de Roma pela Conferência de Plenipotenciários das Nações Unidas.

corpo diplomático do Brasil, já antes da Conferência, integrava uma Comissão Preparatória para o Estabelecimento de um Tribunal Penal Internacional. Durante a Conferência participou ativamen-

8 MIRANDA, Nilmário. "Concepção, Estrutura e Funcionamento da Comissão de Direitos Humanos da Câmara dos Deputados". In A Nova Esfera Pública da Cidadania. João Pessoa: Editora Universitária/UFPB, 1996, p. 60.

9 Para exemplos de tortura e violência policial nos dias de hoje ver Revista Veja, 01.11.1995, p. 28-35; Revista Isto É, 12.01.2000, p. 46-47. Sobre os horrores da tortura na época da ditadura ver Revista Veja, 09.12.1998, p. 42-53. 
te, coordenando grupos de negociações sobre tópicos relevantes para o futuro funcionamento do Tribunal. Segundo o Deputado NILMÁRIO MIRANDA, ex-presidente da Comissão de Direitos Humanos da Câmara dos Deputados, "podemos dizer que nossos representantes internacionais tudo fizeram para colocar em prática o art. $7^{0}$ do Ato das Disposições Constitucionais Transitórias, da Constituição Federal, que preceitua: 'O Brasil propugnará pela formação de um tribunal internacional de direitos humanos". 10

A Comissão de Direitos Humanos da Câmara participou da terceira reunião da Comissão Preparatória para o estabelecimento do Tribunal na sede da ONU em Nova Iorque, a convite da organização nãogovernamental internacional Parliamentarians For Global Action. "Participamos desse importante evento em que debatemos como as legislações nacionais devem se adaptar à nova jurisdição internacional. Voltamos convictos de que os óbices que têm sido apresentados nesse sentido podem facilmente ser removidos, caso haja vontade política para fazer prevalecer os valores e princípios maiores, derivados da Declaração Universal dos Direitos Humanos e claramente contemplados pela nossa Constituição", ${ }^{11}$ destacou o então Presidente da Comissão.

Ogoverno brasileiro também se mostrou favorável ao Tribunal, nas palavras do
Presidente FERNANDO HENRIQUE CARDOSO: "Nós achamos que qualquer pessoa que infrinja os direitos humanos deve, primeiro, ser julgada pelo Tribunal Penal Internacional, que o Brasil apóia”. ${ }^{12}$

O Brasil foi o 94ํ país a assinar o Estatuto de Roma, em 7 de fevereiro de 2000, e o processo de ratificação está em curso. Atualmente 114 países firmaram sua adesão e 21 já ratificaram-na. ${ }^{13} \bigcirc$ Tribunal Penal Internacional entrará em vigor após a $60^{\mathrm{a}}$ ratificação.

O secretário de Estado de Direitos Humanos, JOSÉ GREGORI, anunciou que "Este é um passo muito importante para o Brasil, que de um ano para cá tem colocado em prática uma política pública de direitos humanos". ${ }^{14}$

A criação do TPI demonstra a força extraordinária que os Direitos Humanos adquiriram na agenda internacional, caracterizando-se como um marco significativo na história brasileira e mundial.

\subsection{Características gerais do Tribunal Penal Internacional}

Após as duas grandes guerras, a discussão em torno da criação de uma Corte internacional criminal permanente cresceu e ganhou força. Essa tomada de consciência coletiva está expressa no preâmbulo do Estatuto de Roma, que criou o Tribunal "tendo presente que, neste século, milhões

10 O que é o Tribunal Penal Internacional. Brasília: Câmara dos Deputados, Coordenação de Publicações, 2000, p. 8.

11 Idem.

12 Folha de São Paulo, edição nacional, 10.03.2000, p. 1-8.

13 Folha de São Paulo, edição São Paulo, 04.02.2000, p. 1-5.

14 Dados de outubro de 2000. Em maio de 2001, o Estatuto conta com 139 assinaturas e 32 ratificações. 
de crianças, mulheres e homens têm sido vítimas de atrocidades que desafiam a imaginação e chocam profundamente a consciência da humanidade; reconhecendo que esses graves crimes constituem uma ameaça para a paz, a segurança e o bemestar da humanidade; afirmando que os crimes mais graves que preocupam a comunidade internacional em seu conjunto não devem ficar sem castigo (...); decididos a pôr um fim à impunidade dos autores desses crimes e contribuir assim para a prevenção de novos crimes (...)"

GILBERTO SABOIA aponta como circunstâncias que contribuíram para que esse resultado fosse alcançado antes do final desse século: o fim da guerra fria, a globalização e a interdependência entre nações e a irrupção de conflitos étnicos, raciais e religiosos que resultaram em catástrofes humanitárias colocando em risco a paz e a segurança internacionais. ${ }^{15}$

Tribunal Penal Internacional será uma jurisdição internacional permanente, dotada de independência para julgar e responsável para atuar em casos de violações mais graves aos direitos humanos que preocupam a comunidade internacional em seu conjunto.

Será competente para processar indivíduos, e não Estados, quebrando de certa forma a tradição internacional nesse ponto. $\mathrm{O}$ art. 5ำ do Estatuto de Roma estipula que a jurisdição do Tribunal se limitará aos crimes mais graves que preocupam a comunidade internacional em seu conjunto. São eles: o crime de genocídio, os crimes contra a humanidade, os crimes de guerra e o crime de agressão. Cada espécie de crime recebe minuciosa tipificação.

Os crimes de genocídio compreendem atos praticados com a intenção de destruir total ou parcialmente um grupo nacional, étnico, racial ou religioso. Entre os crimes contra a humanidade, destacamos o extermínio, a escravidão, a deportação ou transferência forçada de populações, a tortura, a prostituição forçada, o desaparecimento forçado de pessoas e o crime de apartheid. $\bigcirc$ rol dos crimes de guerra é também bastante extenso e o crime de agressão ainda depende da aprovação de um dispositivo.

A atuação do Tribunal obedecerá ao princípio da complementaridade, ou seja, de forma complementar à jurisdição interna dos Estados-partes. $\bigcirc$ Estado terá preferência para julgar o criminoso. $\bigcirc$ caso será inadmissível ao Tribunal se Estado que tem jurisdição sobre o fato já o estiver investigando ou processando ou tenha decidido não promover ação penal sobre o indivíduo em questão. Atendendo ao princípio do ne bis in idem, o Tribunal também não poderá processar novamente o indivíduo e tampouco atuará se o caso não for suficientemente grave. $\bigcirc$ Tribunal só poderá atuar, portanto, no caso de omissão do Estado, ausência de imparcialidade, demora injustificada ou incapacidade estatal (art. 17 do Estatuto de Roma).

Os crimes sob a jurisdição do Tribunal jamais prescrevem. Tampouco gozarão de imunidade os Chefes de Estado ou de

15 A criação do Tribunal Penal Internacional. Conferência de abertura do Seminário Internacional sobre o Tribunal Penal Internacional e a Constituição Brasileira. Auditório do Superior Tribunal de Justiça, 29.09.1999 a 01.10.1999. 
Governo que violarem os Direitos Humanos. As normas se aplicarão a todos por igual, sem distinção alguma fundada em função oficial (art. 27).

Tribunal terá jurisdição unicamente sobre crimes cometidos após a entrada em vigor do Estatuto e submeterá apenas os Estados que aceitarem sua jurisdição através da assinatura e ratificação. $\bigcirc$ Estatuto veda expressamente a possibilidade de sua ratificação com reservas, o que significa que o Estado firmatário aceitará integralmente seu texto, com todos os seus dispositivos.

A sede do Tribunal será em Haia, na Holanda, mas poderão ser realizadas sessões em outros lugares, quando conveniente. Será composto por 18 juízes de diferentes nacionalidades, escolhidos por votação secreta em uma sessão da Assembléia dos Estados-partes convocada para tal fim. $\mathrm{Na}$ escolha dos juízes, os Estados deverão levar em consideração a necessidade de que na composição do Tribunal haja representação dos principais sistemas jurídicos do mundo, representação geográfica eqüitativa e representação equilibrada de homens e mulheres (art. 36, $\$ 8^{\circ}$ ).

São princípios expressos no Estatuto a cooperação e a assistência judiciária dos Estados. O regime de cooperação internacional e assistência judiciária estipula a obrigação geral dos Estados-partes de cooperar plenamente com o Tribunal. As legislações nacionais também devem adotar formas compatíveis com o Estatuto. Somente atendendo aos princípios da complementaridade e da cooperação será possível estabelecer um Tribunal Penal Internacional independente e efetivo.

objetivo do Tribunal Penal Internacional é garantir a justiça internacional. Foi concebido com as melhores intenções possíveis, segundo ideais elevados. Os princípios expressos no Estatuto norteiam sua aplicação impedindo que abusos sejam cometidos. As normas encontram seu fundamento de validade nos distintos fins do Estatuto, não podendo contrariá-los.

O Subsecretário-geral de Assuntos Políticos do Itamaraty, embaixador IVAN CANNABRAVA, em depoimento à Comissão de Relações Exteriores e Defesa Nacional da Câmara dos Deputados, no dia 20 de maio de 2000, assinalou que "no entendimento do Governo brasileiro, o texto aprovado contém os elementos necessários ao estabelecimento de uma Corte penal eficiente, imparcial e independente". ${ }^{16}$ Não podemos abrir mão de tão valioso organismo em prol dos Direitos Humanos.

\section{Possíveis obstáculos à adesão brasileira ao Tribunal Penal Internacional: aspectos constitucionais}

\subsection{A Constituição brasileira e o Estatuto de Roma}

Já assinalamos a importância do dispositivo do art. 7o do Ato das Disposições Constitucionais Transitórias, segundo o qual o Brasil propugnará pela criação de um 
tribunal internacional de direitos humanos. A concretização desse objetivo dar-se-ia através da adesão do Brasil ao Tribunal Penal Internacional criado em 17 de julho de 1998 em Roma. Para tanto, bastaria firmar o Estatuto de Roma (já o fizemos em 7 de fevereiro de 2000) e ratificá-lo, ou seja, incorporá-lo ao nosso ordenamento interno.

Tendo em vista que, para o sistema jurídico brasileiro, os tratados internacionais possuem hierarquia de lei ordinária (ver item 4), o Estatuto de Roma, antes da incorporação, deverá sofrer um controle de constitucionalidade prévio a fim de evitar problemas posteriores.

As principais questões suscitadas dizem respeito à prisão perpétua e à entrega de nacionais, previsões do Estatuto de Roma que seriam incompatíveis com o nosso texto constitucional e que inviabilizariam a adesão brasileira ao Tribunal. Com a colaboração dos ensinamentos de alguns juristas, e amparados por uma interpretação sistemática do texto constitucional, procuraremos demonstrar que tais incompatibilidades são apenas aparentes e superáveis.

\subsection{A prisão perpétua}

As penas de caráter perpétuo, especialmente a prisão perpétua, têm sido proibidas em Constituições de vários países. No Brasil essa proibição já é uma tradição constitucional. ${ }^{17}$
A nossa Constituição atual prevê, no art. 5ํ, XLVII, $b$, que não haverá penas de caráter perpétuo. $\mathrm{O}$ art. 77 do Estatuto de Roma estabelece quais serão as penas apli-

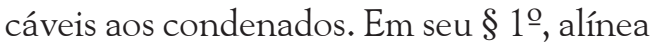
$b$, admite a aplicação da pena de prisão perpétua quando justificada pela extrema gravidade do crime e pelas circunstâncias pessoais do condenado.

A previsão da pena de prisão perpétua pelo Estatuto de Roma inviabilizaria a adesão do Brasil ao Tribunal Penal Internacional dado o flagrante confronto com a nossa Constituição.

Mas alguns de nossos eminentes juristas revelam que essa incompatibilidade é apenas aparente. SYLVIA STEINER aponta que a previsão da pena de prisão perpétua pelo Estatuto de Roma resultou muito mais de uma tentativa de agradar a gregos e troianos. A inexistência da previsão da pena de morte teria levado a Comissão de Direito Internacional da ONU a incluir a pena de prisão perpétua como forma de "compensar" essa ausência, injustificável para os países assentados no sistema da common law, que defendiam ser a pena capital justa e necessária para dar credibilidade à Corte. Apesar da oposição dos países baseados na civil law (caso brasileiro), guiados por outra concepção de pena, venceu a corrente conciliadora, prevalecendo a previsão da pena perpétua em lugar da pena de morte. ${ }^{18}$

17 Ver LUISI, Luiz Benito Viggiano. "A prisão perpétua no Estatuto da Corte Penal Internacional e na Constituição Brasileira". Seminário Internacional sobre o Tribunal Penal Internacional e a Constituição Brasileira. Auditório do Superior Tribunal de Justiça, 29.09.1999 a 01.10.1999. 
A prisão perpétua, portanto, figurou no Estatuto apenas como hipótese excepcional, em situações limites, sendo suscetível de revisão e redução após 25 anos de cumprimento (art. 110, § 3으).

sistema constitucional brasileiro, apesar de proibir a prisão perpétua, admite a pena de morte em caso de guerra declarada (art. 5ำ XLVII, a da CF). O Código Penal Militar também prevê extenso rol de crimes militares em tempo de guerra puníveis com a morte (arts. 355 a 408). Uma interpretação sistemática nos levaria a concluir que a vedação da prisão perpétua pelo nosso ordenamento não pode ser tomada em termos absolutos, já que nem a pena de morte é proibida por completo.

Além disso, o Supremo Tribunal Federal adota o entendimento de que a proibição constitucional da pena de prisão perpétua aplica-se apenas em âmbito interno, não podendo restringir o legislador estrangeiro, muito menos o internacional. Esse raciocínio tem levado o Pretório Excelso a deferir extradições para países que adotam a pena perpétua, atendendo ao princípio da territorialidade da nossa lei penal. ${ }^{19}$ Tais argumentos conduzem à conclusão de que não há incompatibilidade real entre o Estatuto de Roma e a Constituição Brasileira no tocante à prisão perpétua. Essa vedação restringe apenas o judiciário interno, não se aplicando em nível internacional.

\subsection{Extradição x entrega}

A extradição é a entrega de um indivíduo de um Estado a outro para julgamen- to. É proibida pelo art. 5oำ incisos LI e LII da Constituição Federal nos seguintes termos:

$$
\text { "Art. 5(...) }
$$

LI - nenhum brasileiro será extraditado, salvo o naturalizado, em caso de crime comum, praticado antes da naturalização, ou de comprovado envolvimento em tráfico ilícito de entorpecentes e drogas afins, na forma da lei;

LII - não será concedida extradição de estrangeiro por crime político e de opinião."

O art. 89 do Estatuto de Roma, em aparente conflito com nossa norma constitucional, prevê a entrega de nacionais para o Tribunal Penal Internacional. A entrega a que se refere o Tribunal, entretanto, é um instituto distinto da extradição. A fim de evitar controvérsias, o próprio Estatuto diferencia os dois institutos no art. 102: "Por 'entrega' se entenderá a entrega de um indivíduo por um Estado ao Tribunal, em conformidade com o disposto no presente Estatuto; por 'extradição' se entenderá a entrega de um indivíduo por um Estado a outro, em conformidade com o disposto em um tratado, convenção ou no direito interno".

A incompatibilidade, também neste caso, é aparente. TARCISO DAL MASO JARDIM ${ }^{20}$ aponta que "não se trata do antigo instituto da extradição, que se reporta à entrega de uma pessoa de uma jurisdição soberana a outra. Trata-se da entrega sui generis, em que um Estado transfere deter- 
minada pessoa a uma jurisdição penal internacional que ajudou a construir". ${ }^{21}$

instituto da entrega é baseado no princípio da complementaridade e cooperação entre Estados-partes e Tribunal, para que este realize um julgamento justo e imparcial.

\subsection{A PEC 203/2000}

Reconhecendo que as incompatibilidades do Estatuto de Roma com a Constituição Federal são apenas aparentes, a Proposta de Emenda à Constituição apresentada pelo Deputado NILMÁRIO MIRANDA (PEC203/ 2000) não prevê modificações substanciais no texto constitucional - relacionadas à prisão perpétua ou à extradição -, limitando-se a incluir, no art. $5^{\circ}$ da CF, um $3^{\circ}$ parágrafo com a seguinte redação:

"A República Federativa do Brasil poderá reconhecer a jurisdição do Tribunal Penal Internacional nas condições previstas no Estatuto aprovado em Roma no dia 17 de julho de 1998."

$\mathrm{Na}$ justificativa da Proposta, em tramitação na Câmara, o Deputado ressalta que "apesar de esclarecidos os pontos mais polêmicos, compreendemos mister que haja uma disposição constitucional a fim de melhor situar a questão da jurisdição do Tribunal Penal Internacional, de forma a não restar qualquer dúvida em relação a sua pertinência com a legislação brasileira".

Já apontamos que o art. 7ํ do ADCT diz que "o Brasil propugnará pela formação de um tribunal internacional de direitos hu- manos" e que os Direitos Humanos possuem supremacia em relação às demais normas (art. 60, § 4ํo IV) e são dotados de prevalência (art. 4⿳⺈, II). Portanto, restando eventual incompatibilidade do Estatuto de Roma com a nossa Constituição, ela deverá ser dissipada, mesmo que com sacrifício de normas internas, que não podem prevalecer sobre os princípios universais de defesa dos direitos humanos.

\section{Otimização do sistema: como superar outros entraves constitucionais em relação aos tratados internacionais de direitos humanos}

\subsection{Posição hierárquica dos tratados de direitos humanos no ordenamento jurídico brasileiro}

A posição oficial do Brasil quanto aos tratados internacionais é no sentido de que, após incorporados à ordem interna, eles passam a vigorar com o status de lei ordinária. Nessa condição, são passíveis de controle de constitucionalidade e podem inclusive ser revogados por normas ordinárias posteriores que contenham dispositivos contrários (lex posterior derogat priori). Escrevem nesse sentido juristas como MANOEL GONÇALVES FERREIRA FILHO e FRANCISCO REZEK, 22 sendo acompanhados pela jurisprudência do Supremo Tribunal Federal.

21 O que é o Tribunal..., p. 31.

22 Direito Internacional Público. 5. ed., São Paulo: Saraiva, 1995, p. 103 e ss. 
CANÇADO TRINDADE e FLÁVIA PIOVESAN, entretanto, sustentam tese contrária. ${ }^{23}$ Por força do $§ 2^{\circ}$ do art. $5^{\circ}$ da Constituição, os direitos internacionais decorrentes de tratados assinados pelo Brasil teriam hierarquia de norma constitucional.

Confrontemos as opiniões. $\mathrm{O} \S 2^{\mathrm{O}} \mathrm{do}$ art. $5^{\circ}$ da CF possui a seguinte redação:

"Título II. Dos Direitos e Garantias Fundamentais.

Art. 5o (...)

$\S 2$ o Os direitos e garantias expressos nesta Constituição não excluem outros decorrentes do regime e dos princípios por ela adotados, ou dos tratados internacionais em que a República Federativa do Brasil seja parte."

A leitura desse dispositivo constitucional, considerando que ele está incluído no Título que trata dos Direitos e Garantias Individuais, nos faz concluir que, além dos direitos previstos no rol do art. 5ำ, a Constituiçãao incorporaria outros que lhe são afins, inclusive os decorrentes de tratados internacionais firmados pelo Brasil nesse sentido. Ora, segundo esse entendimento, os tratados internacionais de Direitos Humanos incorporados pelo Brasil conteriam princípios de natureza constitucional e somar-se-iam àqueles já arrolados no texto maior.

MANOEL GONÇALVES FERREIRA FILHO, entretanto, diz que "se o Brasil incorporar tratado que institua direitos fun- damentais, estes não terão senão força de lei ordinária. Ora, os direitos constitucionais outros têm a posição de normas constitucionais". E finaliza: "ou seja, haveria direitos fundamentais de dois níveis diferentes: um constitucional, outro meramente legal". 24

O respeitável autor admite, pois, que os direitos fundamentais podem ser hierarquizados: haveria alguns que, por terem sido previstos constitucionalmente, seriam superiores e condicionariam outros que o legislador constituinte não incorporou em seu rol exemplificativo. Tal conclusão do autor diverge brutalmente do princípio da unidade dos Direitos Humanos. Todos os Direitos Humanos são igualmente importantes, não há como estabelecer distinções hierárquicas. Além disso, sendo os tratados humanitários equivalentes às leis ordinárias, poderiam ter seus dispositivos revogados e, o que é inadmissível, resultariam na impossibilidade de cumprir as obrigações assumidas em âmbito internacional.

Assim, uma simples lei ordinária elaborada segundo condições políticas momentâneas e atendendo a certos interesses - seria capaz de promover a inexecução de direitos e garantias do ser humano reconhecidos por toda a comunidade internacional. Um tratado em pleno vigor, obrigando a República, poderia deixar de ser cumprido porque o Congresso esqueceu-se de que existia o compromisso e legislou em sentido destoante dele. ${ }^{25}$

23 Os direitos humanos e o direito internacional, p. 7-62 e 115-138.

24 Direitos humanos fundamentais. 2. ed., São Paulo: Saraiva, 1998.

25 ARAUJO. Nadia. "A Internalização dos Tratados no Brasil e os Direitos Humanos". In Os direitos humanos e o direito internacional, p. 100. 
Uma parcela considerável da doutrina, ao interpretar o art. 5으, $\S 2^{\circ}$, entende que o legislador constituinte deu hierarquia constitucional aos direitos humanos protegidos nos tratados ratificados pelo Brasil, em consonância com o marco que a CF de 1988 representou para os Direitos Humanos no país. Essa opinião seria reforçada pela prevalência dos Direitos Humanos em nível internacional expressa no art. 4o, II e pela consagração da dignidade da pessoa humana como fundamento da República Federativa do Brasil (art. 1ํㅡㄹ III), segundo uma interpretação sistemática.

O Supremo Tribunal Federal, infelizmente, adota a tese segundo a qual não existe hierarquia entre as normas ordinárias de direito interno e as decorrentes de atos ou tratados internacionais. ${ }^{26}$

A Proposta de Emenda à Constituição sobre a Reforma do Poder Judiciário, em tramitação no Senado Federal sob no 29 / 2000, prevê a inclusão de outro parágrafo no art. $5^{\mathrm{O}}$ que solucionaria a controvérsia:

$$
\text { "Art. 5 (...) }
$$

§ 3o Os tratados e convenções internacionais sobre direitos humanos aprovados, em cada Casa do Congresso Nacional, em dois turnos, por três quintos dos votos dos respectivos membros, serão equivalentes às emendas constitucionais."

A redação da PEC, ainda que desnecessária para os autores que defendem que o texto constitucional por si só já resolve a questão, é uma previsão importante e que trará melhoras ao sistema de Direitos Humanos brasileiro. Com a dirimição da controvérsia, o Brasil estará avançando na direção da universalidade de tratamento dos Direitos Humanos, segundo a melhor orientação.

\subsection{A hierarquia de tratados e o Estatuto de Roma}

O Estatuto de Roma do Tribunal Penal Internacional possui natureza jurídica de tratado internacional. ${ }^{27}$ Assim, como a maioria dos tratados internacionais, é uma convenção multilateral que representa a manifestação de vontade dos Estados signatários.

Por configurar um tratado internacional, o Estatuto de Roma está diretamente envolvido com as questões discutidas no item anterior. A incorporação do Estatuto ao ordenamento jurídico brasileiro sofre, conforme já apontado, um controle de constitucionalidade prévio, suscitando questões relacionadas à prisão perpétua e entrega de nacionais.

Ainda que, após exame minucioso, tenhamos verificado que não há incompatibilidades reais entre o Estatuto de Roma e a Constituição Brasileira, a incorporação desse tratado ao ordenamento nacional não estará permanentemente a salvo de investidas legais.

Se o Estatuto de Roma adentrar o nosso ordenamento com o status de lei or-

26 Ver RE 8.004; HC 77.631/SC; ADIn 1.480; Carta Rogatória 8.279.

27 JARDIM, Tarciso Dal Maso. "O Tribunal Penal Internacional e sua Importância para os Direitos Humanos". O que é o Tribunal..., p. 16. 
dinária, estará permanentemente à mercê de um controle de constitucionalidade, podendo ter seus dispositivos declarados inconstitucionais. Também como equivalentes à legislação ordinária, estarão sujeitos a quaisquer modificações introduzidas por leis comuns na ordem jurídica. O Estatuto poderá ser revogado total ou parcialmente, segundo esse entendimento.

É inadmissível que o Brasil, após ter aceitado a jurisdição do Tribunal, deixe de se submeter às suas regras por simples capricho do legislador infraconstitucional. $\bigcirc$ descumprimento de tratado configura ilícito internacional, sendo passível de sanções. Ao se comprometer com um organismo internacional de Direitos Humanos, o Brasil não pode contrariar suas disposições. Ademais, é princípio expresso no Estatuto que os Estados-partes têm a obrigação de colaborar plenamente com o Tribunal e ajustar suas legislações internas ao Estatuto de Roma para seu eficaz funcionamento.

Imperioso, portanto, que o problema em torno da incorporação de tratados humanitários ao direito brasileiro seja resolvido. De alguma maneira, teremos que reorganizar nosso ordenamento para promover uma melhor atuação do Tribunal. Há duas soluções possíveis. Ou opera-se uma mudança fundamental de mentalidade ${ }^{28} \mathrm{em}$ nossos juristas de modo que possam reconhecer que a Constituição, por si só, já é suficientemente completa ao estabelecer o caráter constitucional dos direitos huma- nos advindos de tratados internacionais ou, para remediar a situação, aprova-se a mudança sugerida pela PEC 29/2000, que prevê que tratados de direitos humanos poderão ser incorporados como emenda constitucional. Essa evolução só contribuirá para otimizar nosso sistema de modo a recepcionar da melhor maneira possível os novos ditames humanitários, viabilizando a concretização do art. $7^{\circ}$ do Ato das Disposições Constitucionais Transitórias.

\section{No Limiar de um novo século: o papel do Brasil perante o mundo na luta pelos direitos humanos}

\subsection{Os direitos humanos no contexto internacional}

Um dos fatos mais marcantes deste fim de século consiste na força extraordinária que os Direitos Humanos adquiriram na agenda internacional. ${ }^{29} \mathrm{~A}$ conscientização em torno dos Direitos Humanos movimenta países e organizações não-governamentais de todo o planeta. $\mathrm{O}$ vigor extraordinário que o caracteriza na esfera internacional também é encontrado na área doméstica de quase todos os países, inclusive o Brasil. ${ }^{30}$

Inaugurado pela Declaração Universal de 1948, o Direito Internacional dos Direitos Humanos não pára de crescer. WAGNER ROCHA D'ANGELIS aponta que "os direitos humanos são cada vez me-

28 CANÇADO TRINDADE. Os direitos humanos e o direito internacional, p. 61.

29 ALVES, José Augusto Lindgren. A arquitetura internacional dos direitos humanos. São Paulo: FTD, 1997, p. 12. 
nos matéria da jurisdição doméstica dos Estados, para cada vez mais interessar e obrigar a totalidade da vida internacional". ${ }^{31}$

Nesse sentido, é forçoso reconhecer que a tutela dos Direitos Humanos não pode ficar reduzida aos limites de um Estado. A violação desses Direitos "preocupa a comunidade internacional em seu conjunto", 32 cumprindo adotar medidas não apenas no âmbito nacional, mas pela comunidade internacional.

Verificamos que as Declarações e Convenções de Direitos Humanos multiplicam-se dia a dia e que a enorme maioria dos países já se conscientizou da sua importância incorporando seus princípios às Constituições.

A conscientização generalizada, entretanto, não foi suficiente para conter o avanço da barbárie e da violência ao ser humano ainda praticados em todos os cantos do mundo. Faltava um organismo internacional independente, criado especialmente com o fim de punir os maiores crimes contra a humanidade: um Tribunal Internacional de Direitos Humanos. O Tribunal Penal Internacional virá preencher essa lacuna.

\subsection{0 papel do Brasil na concretização do Tribunal}

$\bigcirc$ Brasil, ciente da necessidade de um organismo internacional de Direitos Humanos, já em 1988 insculpiu na Carta Magna que nosso país lutaria pela criação do Tribunal Internacional de Direitos Humanos (art. 7ํㅡㄹ ADCT).
Hoje esse organismo está muito próximo de se tornar uma realidade. Mais do que a satisfação de uma norma constitucional, a instalação do Tribunal Penal Internacional é um enorme passo brasileiro em favor da humanidade, é a expressão do que almejamos para o novo século.

Nos últimos cem anos presenciamos duas Guerras Mundiais. Massacres étnicos. Terrorismo. Genocídio. Tortura. Desaparecimento forçado de pessoas. Bombas nucleares. Campos de concentração. Racismo. Dilapidação de povos indígenas. Guerras civis sangrentas. Extermínio. Apartheid. Choro, sangue e desespero. Saímos de um século manchado. Dois mil anos depois da revelação cristã, o homem ainda não aprendeu a respeitar seu semelhante.

A esperança, no entanto, ainda não deixou petrificar nossos corações. Um novo milênio se aproxima e não queremos novamente sentir vergonha de nós mesmos. Não queremos mais ver nossos irmãos - de qualquer raça, religião, nacionalidade ou condição social - serem profundamente atingidos na sua condição de seres humanos.

$\bigcirc$ advento de um novo século incita novo ânimo aos Direitos Humanos. A criação de um Tribunal Penal Internacional aviva nossas esperanças. O Brasil cumprirá seu papel. E a humanidade deixará de ser tão desumana.

\section{Conclusão}

Não pretendemos, com esse estudo, esgotar a problemática de Direitos Huma-

31 Organização popular e prática da justiça. Curitiba: Centro Heleno Fragoso pelos Direitos Humanos, 1992, p. 36.

32 Preâmbulo do Estatuto de Roma. 
nos no Brasil. Nosso país é rico em miséria social, violência, injustiça e desigualdades e pobre em instrumentos para extirpá-los.

\section{A Constituição de 1988 consagrou} os Direitos Humanos como princípio fundamental e norteador do ordenamento. Mas estamos cansados de ouvir que eles só existem no papel, que carecem de efetividade, que constam apenas formalmente para impressionar.

Tribunal Penal Internacional, ao contrário, é uma proposta séria e concreta. Tem tudo para dar certo. Basta vontade política e um pouco de altruísmo. $\bigcirc$ Brasil, felizmente, manifestou-se favoravelmente ao Tribunal desde que promulgou a Constituição em 1988. O art. 7ํ do Ato das Disposições Constitucionais Transitórias está prestes a se realizar.

Esse trabalho teve por objetivo demonstrar a importância desse acontecimento para os Direitos Humanos no Brasil. Sabemos que o Tribunal Penal Internacional não resolverá nossos enormes problemas humanitários. Mas é um grande passo numa caminhada que está apenas começando. É com esse novo ânimo que o Brasil adentrará o novo século.

\section{Referências bibliográficas}

ALVES, José Augusto Lindgren. A arquitetura internacional dos direitos humanos. São Paulo: FTD, 1997.

BOUCAULT, Carlos Eduardo de Abreu e ARAUJO, Nadia (orgs). Os direitos humanos e o direito internacional. Rio de Janeiro: Renovar, 1999.

BOURDON, William e DUVERGER, Emmanuelle. La Cour pénale internationale: le statut de Rome. Paris: Éditions du Seuil, 2000.
BRASIL. Comissão de Direitos Humanos da Câmara dos Deputados. O que éo Tribunal Penal Internacional. Brasília: Câmara dos Deputados, Coordenação de Publicações, 2000.

BRASIL fará parte do Tribunal de Haia. Folha de São Paulo, edição São Paulo, p. 1-5, 04.02.2000.

BRASIL. Presidente (1994: Fernando Henrique Cardoso). Direitos Humanos: novo nome da liberdade e da democracia. Brasília: Presidência da República, Secretaria de Comunicação Social, Ministério da Justiça, Ministério das Relações Exteriores, 1995.

BUSSI, Nilton. "Direito Penal Internacional Globalização". In O Estado do Paraná. Curitiba, caderno Direito e Justiça, 11.06.2000.

D'ANGELIS, Wagner Rocha. Organização popular e prática da justiça. Curitiba: Centro Heleno Fragoso pelos Direitos Humanos, 1992.

. Direitos humanos: a luta pela justiça. Rio de Janeiro: Comissão Brasileira Justiça e Paz, 1989.

FERREIRA FILHO, Manoel Gonçalves. Direitos humanos fundamentais. 2. ed., São Paulo: Saraiva, 1998.

FHC apóia desfecho do caso Pinochet. Folha de São Paulo, p. 1-8, 10.03.2000.

LEAL, Rogério Gesta. Direitos humanos no Brasil: desafios à democracia. Porto Alegre: Livraria do Advogado, 1997.

LUISI, Luiz Benito Viggiano. "A prisão perpétua no Estatuto da Corte Penal Internacional e na Constituição Brasileira". Seminário Internacional sobre o Tribunal Penal Internacional e a Constituição Brasileira. Auditório do Superior Tribunal de Justiça, 29 de setembro a $1^{\circ}$ de outubro de 1999. Arquivo da Internet. Capturado em 18.06.2000. Disponível no site: http://www. cjf.gov.br/

LYRA, Rubens Pinto (org.). A nova espera pública da cidadania. João Pessoa: Editora Universitária/ UFPB, 1996.

MARTINEZ, Paulo. Constituição: legalidade versus realidade. São Paulo: Moderna, 1991. 
MORAES, Alexandre de. Direitos humanos fundamentais: teoria geral, comentários aos arts. $1^{\circ}$ a $5^{\circ}$ da Constituição da República Federativa do Brasil, doutrina e jurisprudência. São Paulo: Atlas, 1998.

NASCIMENTO, Gilberto. Tortura anunciada. Isto É, 12.01.2000, p. 46-47.

O PODER da pauleira e do choque. Veja, 01.11.1995, p. 28-35.

OS TORTURADORES do regime militar. Veja, 09.12.1998, p. 42-53.

OLIVEIRA, Joelíria de Castro. Tribunal Penal Internacional. Folha de São Paulo, 11.07.2000, p. A3.
REZEK, José Francisco. Direito Internacional Público: curso elementar. 5. ed., rev. e atual. São Paulo: Saraiva, 1995.

SABOIA, Gilberto Vergne. A criação do Tribunal Penal Internacional. Conferência de abertura do Seminário Internacional sobre o Tribunal Penal Internacional e a Constituição Brasileira. Auditório do Superior Tribunal de Justiça, 29 de setembro a 1 o de outubro de 1999. Arquivo da Internet. Capturado em 18.06.2000. Disponível no site: http:// www.cjf.gov.br/ 